\title{
Barber-Client Communication: What They Talk and What Secret They Share in Barber Armchairs!
}

\author{
Berber-Müşteri İletişimi: Berber Koltuklarında Neler Konuşuyor, \\ Hangi Sırları Paylaşıyorlar!
}

\section{Assoc. Prof. Dr. Rüçhan Gökdăg}

\begin{abstract}
People who live and work in cities have to go hairdressers regularly in Turkey. And if there is no extraordinary state, they prefer to go to the same hairdresser. The longevity character of hairdresser-customer relation; turns this relation to an interpersonal communication. This affiliation sometimes has gone too far to share some secrets.

In today's world, communication in family, in work life, and between close friends has been gradually dissolving. Nobody has time to listen to nobody. People talk less with each other. Barber armchairs provide the enough time to customers whose husband and wife or close friends do not give them to talk. In this context, the time which customers spent in barbers' armchair has been passing through with a nice conversation, discharge and sharing the mental distresses. This study has been conducted to reveal the subjects talked in between hairdresser and his/her customers, and how much the talks have been repeated at later comings. Twenty seven hairdressers working in Eskisehir were interviewed. After that, the results discussed and created some groups of theme to analyze.
\end{abstract}

Keywords: Hairdresser, Communication, Interpersonal Communication, Sharing Secrets, Coping With Stress

\section{Öz}

Türkiye'de; kentlerde yaşayan ve çalışan insanlar; düzenli olarak berbere gitmek durumundadirlar. Olağanüstü bir durum olmadikça da hep aynı berbere gitmeyi tercih etmektedirler. Berberlerin müşterileriyle olan ilişkilerinin sürekliliği; aralarındaki ilişkiyi giderek kişilerarası iletişsime dönüş̧ürmektedir. Bu yakınlık bazen, saklı kalması gereken çeşitli sırların paylaşımına kadar gidebilmektedir.

Günümüz dünyasında aile içi, iş yaşamı ve arkadaşlar arasindaki iletişim giderek zayıflamaktadır. Kimsenin kimseyi dinleyecek zamanı yok. Insanlar birbirleriyle daha az konuşuyor. Berber koltuklarl; eşlerin ve arkadaşların birbirlerine ayıramadiğı o zamanı yeterince sağlamaktadır. Bu bağlamda; müşterinin koltukta oturduğu süre iki kişi arasındaki hoş bir sohbete, içini dökmeye, sıkıntıları paylaşmayla geçmektedir. Bu çalışma müşteri-berber arasında konuşulan konular, bunların sonraki gelişlerde tekrarı bakımından kadın ve erkekler arasında fark olup olmadığın ortaya koymak amacıyla yapılmıştır. Araştırma için Eskişehir ilinde çalışan 27 berberle yüz yüze görüşmeler yapılmiştır. Sonuçlar tartışılmış ve tematik gruplar oluşturularak analiz yapılmıştır.

Anahtar Kelimeler: Berber, İletişim, Bireylerarası İletişim, Sır Paylaşımı, Stresle Başa Çıkma

Assoc. Prof. Dr. Rüçhan Gökdağ, Anadolu University Faculty of Communication Sciences, rgokdag@anadolu.edu.tr 


\section{Introduction}

It is possible to influence someone's life by touching and to take practical steps for this. Lack of physical contact in people's lives could lead to such feelings as abstraction from the environment and loneliness. If we do not establish communication with our own body, then it may not be easy to contact and communicate with our environment. Individuals who do not have a positive relationship with themselves will have problems with their connection with the world and develop a personal perception as if they contradict with their environment. It should be remembered that no method can replace a real connection or engagement with the environment. Ideally, individuals' contact with themselves and with others creates intimacy based on increased sensitivity of individuals and increases each other's value. Individuals' efforts to beautify themselves and the positive steps to contribute to their bodies should all be done by the individuals themselves, by others in their close environment or by experts considered to be professionals (Caplan, 1998).

In the study of Canyilmaz (2009), the barber term in Turkish is defined as "the person who deals with cutting, combing and doing hair and beard or the ones who acquires that as a profession, the men's hairdresser, barber". The coiffeur means "hairdresser, barber and beauty parlor".

In the study of Guzel (2013), hairdressers are defined as "the persons who cut, form, dye and do hair care according to the current fashion trends and pleasure of the client". It is mentioned that the main occupation of hairdressers is related with hair however they work in quite verbal interaction with their clients and other hairdressers. It is stated that today the increasing income level of people causes that they care for their appearance more than before and hairdressing profession has become more important by diversification of services of hairdressers as well as hair design.

In the study of Ustuner and Thompson on female hairdresser and client relations, the middle/upper class expectations and difficulties of hairdressers in adaptation period are presented. While, the female hairdressers in Turkey are men and boss-hairdresser concept is common, there is not such a situation in the USA. Ustuner states that it is normal for people keeping arm's length as much as not looking for any physical privacy and at this point it is known that it is said "if, he does his job well, let the apprentice do my hair but he should keep his conduct with me properly". In this study, it is mentioned that the class difference is permanently emphasized to other people intentionally or unintentionally by responding or not responding and it is also observed that hairdressers try to establish dominance over their clients through various strategies. In the study, it is presented that women are tied to their hairdressers loyally and they do not change their hairdressers for years; they cannot stand that their hairdressers whom they trust their hair to call them "you"; most hairdressers come from upstate areas, begin hairdressing from the lowest level and their profession is a transforming aspect for them; a hairdresser must be looking good as well as doing hair perfectly in order to go places in his profession and in hairdresser salons women try to establish superiority on their hairdressers while hairdressers try to establish superiority against each other (http:// www.milliyet.com.tr/sacimi-yapabilirsin-arkadasimolamazsin/pazar/haberdetay/25.09.2011/1442733/ default.htm, Access date: 15.05.2016).

In the interview titled as "we have come to places by this profession" which has been published in Hairist. com.tr (2013), Erbil who is an experienced and popular hairdresser in Istanbul states that; "It is an extremely important privilege for you that a client comes to the parlor and especially requests you. The pleasure and emotion felt by this is a different thing." In this interview, it is mentioned that there are changes in our age; the people who used to come for spending time, entertaining, having a talk and socializing have limited time and they desire to be handled practically; the clients of today cannot stand any mistakes than the past and there is a more investigative client profile while they were not used to questioning in the past. It is stated that a person should have a wide vision, be a good manager who can manage his team well, he should be technically knowledgeable and experienced and patient; it should be known that it is important to bring forward his opinions beyond meeting the expectations of his clients; it is more important to listen than tell; the client psychology should be known well and it should be reflected that the hairdresser tries to make her feel good and by this means it will become possible to keep client flow. Erbil indicates that he cannot stand the clients who try to establish dominance over him due to their economical means 
and mutual respect is needed and it is important to be preferred by being a good hairdresser rather than being a well-known one and he defines himself as "a psychologist with hair design ability" (https://www. hairist.com.tr/mahmut_ebil_hepimiz_bu_meslek_ sayesinde_bir_yerlere_geldik.-278--.html, Access date: 15.05.2016).

In the news titled as "People also go to beauty parlors for social expectations" and in the study of Ozyurt; 120 women who applied to the beauty parlors of Samsun for having an esthetic body were interviewed in order to determine the sociological aspect of attitudes towards objectifying beauty and ugliness in society" According to Ozyurt, "Women inclining towards becoming beautiful aim to become mentally satisfied and meet their expectations in social relations by making partial changes on their bodies rather than becoming biologically healthier. 71 percent of women indicate that beauty parlors provide biological and psychological relief and promote their social relations by performing their care and cleaning." (http:// www.milliyet.com.tr/guzellik-salonlarina--sosyalbeklentiler--icin-de-gidiliyor-pembenar-detayask-1656635/, Access date: 15.05.2016).

In the study of Togan et al. (2014a), it is considered that hairdressers might have an important role in infection of Hepatitis B and C and it is aimed to determine the knowledge and attitudes of 59 women working in hairdressers and beauty parlors of Aksaray province on hepatitis. In the study, the data on socio-demographic characteristics, professional experience, working conditions, knowledge and practices on preventing infection has been gathered. It has been determined that most of the participants do not have sufficient knowledge on self-care and material cleaning and they exhibit wrong behaviors.

In another study of Togan et al. (2014b) conducted in Manisa, again most of 156 participant do not have sufficient knowledge on self care and material cleaning and they exhibit wrong behaviors.

In the study of Baryaman et al. (2011), the Hepatitis $B$ related issues have been analyzed on the craftsmen and employees of the municipality and no increased risk for Hepatitis has been detected on the coiffeurhairdresser staff.
As a result of the study of Sahin et al. (2009) conducted on 124 hairdressers, manicurists and pedicurists working in women hairdressers in Sisli, Istanbul for determining their knowledge and practices related with Hepatitis B, it has been observed that the women hairdresser staff participated in the study do not have sufficient knowledge and practices on Hepatitis B and other blood-borne diseases.

In the study of Boztas et al. (2006), it has been aimed to determine the opinions and practices of 100 people working in 14 coiffeurs, 19 hairdressers and 8 beauty parlors on blood-borne diseases. 56\% of 100 participants have assessed their profession high risky with regards to blood-borne diseases while only $19 \%$ of them had their Hepatitis B injection.

In the study of Guzel (2013), 344 women and men hairdressers of Erzurum have been examined and it has been determined that the most common professional disorder is sleep disorders with $63.8 \%$ and the highest value on professional satisfaction is "relations between staff" and the lowest one is "working hours".

In the study of Mermer et al. (2015), it is presented that the most common health problem of 191 women hairdressers in Bornova, Izmir are related with ergonomics and psychological burden.

\section{Purpose of the Study}

The purpose of this study is to present the topics and shared secrets in barbers-client communication under main themes.

Accordingly, the answers to following questions are sought.

1. What is the profile of hairdressers?
a. Gender of hairdressers
b. Education level of hairdressers
c. Age of hairdressers
d. Work experience of hairdressers

2. What is the profile of clients?

a. How many years have the old clients come to the hairdressers

b. The number of old clients 
c. 1 month service frequency of clients

d. Time that the clients spend in the hairdressers

e. Monthly income of clients sharing their secrets

f. Age range of clients sharing their secrets

g. Occupational status of clients sharing their secrets

h. Marital status of clients sharing their secrets

3. How is the hairdresser-client communication?

a. Secret sharing status of clients

b. Number of secret sharing clients

c. Causes for sharing their secrets

d. Warning of clients for not sharing their secrets with anyone

e. Advice asking status of clients from their hairdressers

4. What are the characteristics of statements they share?

a. Subjects of shared statements: subjects of shared secrets, complaint status of clients and the subjects the clients complain about

b. Depth of shared statements: details of shared secrets

c. Continuity of stated issues: reopening of secret issues

d. Following shared statements: asking questions on a previous subject

5. What are the secrecy/secret sharing attitudes of hairdressers?

a. Sharing a secret with other clients

b. Sharing secrets in different environments

c. Sharing secrets on phone

6. What are the thought of hairdressers on their profession?

a. Negative approach due related with sharing problems

b. Positive approach related with sharing problems

c. Professional evaluations

\section{Limitations}

This study is limited with the accessible hairdressers working in the city center of Eskisehir who accepted to have an interview. The data has been collected by semi-structured interview technique. The number of participant hairdressers is twenty seven. The study is limited with the opinions of the selected hairdressers and generalizability of results is limited.

\section{Method}

"In qualitative studies, the data can be gathered by means of in-depth interview, observation, participant observation and log analysis techniques (Wiersma, as cited in Batu et al., 2004). This study has been conducted by semi-structured interview technique. An interview is a conversation between an interviewer and an interviewee or a group for getting information (Yildirim and Simsek, 2005). According to another definition, an interview is conversations conducted with a person or a group for a particular purpose. The researcher directs these conversations for getting information from the interviewees. (Patton, as cited in Batu et al., 2004). Interviews as the most common clustering method are considered in three ways as the structured, unstructured and semi-structured interviews (Babbie; Berg; Gorden; Nieswiadomy, as cited in Batu et al., 2004). Semi-structured interview is between the structured and unstructured interviews. "Interview form is prepared for getting the same kind of information from different people for inclining towards similar subjects" (Patton, as cited in Yildirim and Simsek, 2008). A set of questions are prepared for using in interviews to apply in semi-structured interviews. These questions are directed by the researchers to each interviewee in the same order however the interviewees are allowed to answer as they wish (Gay; Berg, as cited in Batu et al., 2004).

In the interviews conducted for this study, it has been tried to access opinions of hairdressers on the communication of barbers with their clients, shared secrets, held topics and their knowledge and experience. Consequently, it is tried to present the topics and shared secrets in barber-client communication under main themes and sub-themes.

The researchers held interviews with the randomly selected hairdressers in their own shops. Before, each 
interview, the purpose of the study has been stated and it has been committed that the interviews would be held confidential.

\section{Data Collection Tool}

As aforementioned, the semi-structured interview technique has been applied in the study. In order to compare the answers of interviewed hairdressers, main interview questions which can be answers to the questions listed in the purposes title of the study have been prepared. The researcher has made a trial of these questions with a hairdresser close to his institution. The sound recordings of the interview have been analyzed by an expert and evaluations on the interviewee and the questions have been done and the interview form has been finalized as at the end of the paper.

\section{Determining the Hairdressers Participating in the Study}

In order to determine the hairdressers to be surveyed in the barber-client communication study, the names of hairdressers in Eskisehir city center have been obtained from the Chamber of Barbers and Coiffeurs of Eskisehir and surveyors at the helm of the researchers have visited the coiffeurs and requested permission and support for their study. One of the researchers has met with the coiffeurs who accepted to participate in the study and provided information on the study and in order to create an environment of confidence, indicated that the data to be obtained from the study would only be used for scientific purposes.

\section{Collecting Data}

The date and time of interviews have been agreed with the hairdressers for conducting the study. The interviews have been conducted in between 1-15 April 2016 as previously planned in the pre-interviews with the hairdressers. Before, each interview, the researcher has explained the purpose of the study and mentioned that the contents of interview would not be read by anyone other than the interviewer, their names would be kept confidential and they should feel relaxed and free to state their opinions. The researchers and interviewers have jointly visited the hairdressers and recorded the questions and answers of the interviews by a sound recorder by getting consent of them. The interview questions have been asked in the aforementioned order. If, the questions could not be understood, brief explanations have been provided by paying attention not to influence answers. Moreover, while the previous questions were replied, the following but answered ones were not asked again. Finally after the recording was done, the researchers have thanked the hairdressers for their times and left the shop.

\section{Data Analysis}

The data collected for the study has only been subjected to descriptive analysis. Naturally, when a descriptive analysis is done, the data obtained through interviews are presented originally without adding our opinions and comments as researchers. The following procedure has been followed in data analysis:

- The interview records have been transferred to computer environment without making any changes on them. The text format of sound recordings corresponds to 130 pages. During this transfer the statements of the interviewer and interviewee were written in different characters for easy separation.

- In the reading for checking the texts, the words, sentences or phrases of answers were written by bold characters for easy separation.

- A blank notebook was taken and each interview question has been written as titles at upper right corner by skipping two-three pages. Then, the answers of each hairdresser were combined under the related title by means of bold texts in computer. These answers were sometimes summarized by a single word or a phrase and sometimes written as stated. During this procedure, the answers not included in the interview form but asked during interviews were written at the end of the notebook.

- The answers transferred to the notebook were read and replied answers for each question were tallied. While tallying, the notions, sentences or phrases sometimes used by hairdressers or discovered prematurely were used. These procedures were done on the empty space at left side of the page where the questions were written. By this way, all the answers to a question and the number of hairdressers repeating the same answers have been revealed. 
- The subtitles where the tallied answers given for each answer could be gathered have been decided jointly by an expert.

\section{Reliability Study}

The following procedure has been followed for compliance check of the determined answers and subtitles: Firstly, the hairdresser was selected and interview printout, questions and considered subtitles were given to a second expert. It has firstly been requested from this expert to determine the statements which can be answers for each question and then replace appropriate answers under subtitles. At the end of this procedure, the answers of related hairdressers registered by the researcher have been compared with the answers and subtitles determined by the expert. The reliability analysis has been examined either for the statements with answer characteristics and subtitles where they were gathered. As a result, the reliability level between the researcher and the expert has been found as $95 \%$ for the answers. It has been observed that there is a complete unity in subtitling the answers of the following two hairdressers. For reliability calculation:

\section{Consensus}

Consensus + Dissensus

The study report has been compiled by combining the tallied answers gathered under particular titles at the left side of the notebook and the bold statements in the computer. The bold statements have been used as direct quotes.

\section{Findings and Comments}

\section{Information Related with the Interviewed Hairdressers}

Twenty four of the interviewed hairdressers are men while three of are women; the age average of them is around 37 and their ages vary from 23 to 60 ; nine of them are primary school ( 5 years) graduates while eighteen of them are primary school (8 years) graduates; four of them have job experience around 5-8 years, four around 9-12 years, three around 13-16 years, two around 17-20 years, six around 21-24 years and eight around 25 and higher years of experience.

\section{Information on Client Profiles of The Interviewed Hairdressers}

Clients of four of the interviewed hairdressers have been going to the same shop for 2-5 years, three for 5-8 years, four for 9-12 years, six for 13-16 years, two for 17-20 years, two for 21-24 years and six for 25 years and more. Almost all the hairdressers ( 24 of them) serve 16 and more old clients. The monthly visit frequency of old customers has been indicated by ten of the hairdressers as once, nine hairdresser twice, three hairdresser thrice, five hairdresser four times and more. If, the time the old clients spend at the shop is analyzed, two of the hairdresser have mentioned as the lowest time spent by their clients at the shop as between 10 minutes and less, nine of them as between 10-20 minutes, thirteen of them as between 20-30 minutes, three of them as 60 minutes; twelve of the hairdressers have mentioned that the highest time spent by their clients at the shop as around 1-2 hours, five of them as around 2-3 hours and ten of them as 3 hours and more. If, the income levels of secret sharing clients are analyzed, it is observed that one hairdresser has secret sharing clients from low income level, two of them have secret sharing clients from minimum wage income level, fourteen of them have more secret sharing clients from the middle income level, five of them have secret sharing clients from the higher income level and five of them have secret sharing clients from all income levels. If, the age range of secret sharing clients is analyzed, it has been mentioned by eight hairdressers that these clients are around 20-25, two hairdressers have mentioned that they are around 25-30, ten hairdressers have mentioned that they are around 30-35 and seven hairdressers has mentioned that they are around 40 and older. If, the professional status of secret sharing clients is analyzed, it has been mentioned by sixteen hairdressers that these clients have a profession while they do not know what they are, two hairdressers have mentioned that these clients are university students, three hairdressers have mentioned that they are housewifes, three hairdressers have mentioned that they are factory workers, one hairdresser has mentioned that they are public servants, one hairdresser has mentioned that they are academics and one hairdresser has mentioned that they are manufacturers. If, the marital status of the secret sharing clients is considered, it has been stated by sixteen hairdresser that they are 
married and eight of them have mentioned that they are single and three hairdresser has mentioned that he has clients sharing secrets from all marital status (married, single or divorced).

\section{Information on Hairdresser-Client Communication}

When, the information on secret sharing client is asked, all twenty seven hairdressers mention that they share secrets with their clients. With regards to the number of secret sharing clients, six hairdressers mentioned that they have 5 and fewer clients sharing their secrets with them, ten hairdressers mentioned 6-15 clients, six hairdressers mentioned 20-25 clients, two hairdressers mentioned 40-45 clients, two hairdressers mentioned 100 and more clients and a hairdresser mentioned that he/she did not know an exact number. Eighteen of the hairdressers consider the cause why their clients share their secrets with them as confidence, fifteen as sincerity/being close, thirteen as therapy/we listen to their problems and comfort them, eleven as friendship/companionship, two as touch/contact, one as a habit of long years and one as "it makes more sense to tell foreign". The question on whether their secret sharing clients warn them not to share their secret with anyone else is answered by seventeen hairdressers as "no", four hairdressers as "yes", five hairdresser as "very rare" and one hairdresser as "there are people who warn and do not warn". Twenty two of the hairdressers have mentioned that their secret sharing clients ask for advice related with their secrets.

\section{Information on Characteristics of Shared Communication}

If, the subjects of communication between hairdressers and client are analyzed, it draws attention that the secrets on family/relation issues for 38 times girlfriend/boyfriend, marriage, lover, relationship, love, private life, men, children, close relationship and for 5 times sex life are shared. Other than these, it is observed that the secrets on the business life are shared for 11 times, everything about life for 4 times, money for 3 times, daily exhaustions for 2 times, politics for 2 times, health for 1 time, football for 1 time, education for 1 time and fighting with friends for 1 time.

Allmost all the hairdressers (25) mention that their clients complain about their lives. The subjects which their clients complain about are indicated as twenty two times general working life, hardship of work, financial issues/money, low wage, long working hours, nursing, chores; eleven times family members, lover/ girlfriend/boyfriend, complaints about his spouse/ hardships of marriage, children and longing for family, five times general life problems, two times education (collage, courses and academics) one time eyebrow-mustache problems and one time condition of Turkey.

If, the depth of communication shared between hairdressers-clients is analyzed; sixteen hairdressers have mentioned that they have clients sharing superficially, seven hairdressers have mentioned that they have customers sharing in detail and four hairdressers have mentioned that they have customers sharing both superficially and in detail.

If, the continuity of subjects communicated between hairdresser-client dialogues is considered; fifteen hairdressers have replied the question whether the subjects on shared secrets are reopened as "yes", eight hairdressers have replied as "no", three hairdressers have replied as "rare" and one hairdresser have replied as "it depends".

Related with follow-up of the shared communications, twenty one hairdressers have mentioned that they ask questions to their clients on previously shared subjects, five hairdressers have replied "no" and one hairdresser has replied as "rare".

\section{Information on Keeping/Sharing Secret Attitudes of Hairdressers}

Eighteen hairdressers have replied the question on whether they share the secrets shared by their clients with other clients as "no, I do not", nine hairdressers have replied as "yes, but I share examples without mentioning any name". Fourteen hairdressers have replied the question on whether they share the secrets shared by their clients at other places as "no, I do not", three hairdressers have replied as "yes, I do", ten hairdressers have replied as "yes, but I share a examples without mentioning any name". Twenty three hairdressers replied the question whether they share the secrets shared by their clients on phone as "no, I do not", one hairdresser have replied as "yes, I do", three hairdressers have replied as "yes, but I share a examples without mentioning any name". 


\section{Considerations of Hairdressers about Their Profession}

The hairdressers with a negative perspective for complaint sharing aspect with their clients have mentioned that they are tired of listening problems of their clients, their clients show them as therapy centers even their clients transfer all their problems and complaints to them as if they are "garbage containers" and they cannot share their complaints and problems with their clients as they do not listen or do not want to listen the hairdressers and they cannot be relived.

Five of the barbers reported that they shared problems mutually with their customers, while three of them stated that only their colleagues listened to their problems.

When the professional interaction is taken into account, it is seen that three barbers had good relationships with their customers in terms of information sharing.

When, it comes to professional evaluations as a final finding; most of the hairdressers have indicated that they are not satisfied with their profession and it only makes them exhausted, while 3 hairdressers have mentioned that "thanks to God, I earn well and I am happy with my profession", "It makes me happy to make people beautiful and happy".

\section{Results, Discussion and Recommendations}

Hygiene is emphasized as a very important issue both in the domestic and foreign literatures. It is observed in the study that there are lots of deficiencies and risk related with hygiene. However, while there are important findings on this issue, information on hygiene is rarely observed in the interviews. Gokdag and Unugur (2016) consider that this can be related with cultural characteristics of Turkey. While, especially hygiene must be cared by woman hairdressers, with regard to cultural characteristics of Turkey, it might be considered as shame, accusation, attack or insult to talk or criticize hygiene at hairdressers.

As another interesting finding, it can be presented that politics are not communicated much. There have been some incidents in Turkey where great casualties have been experienced. As a result of bombings admitted by ISIS and Kurdistan Freedom Falcons (TAK), several civilians, soldiers and policemen have lost their lives. The most notable ones of these incidents are July 20, 2015 Suruc, October 10, 2015, February 172016 and March 13, 2016 Ankara bombings and these incidents have caused more than 200 casualties and nearly 800 injuries (Cumhuriyet Newspaper, NTV.com.tr, Dogan News Agency, BBC Turkish and the Statement of the Prime Ministry Coordination Center). In a country where there are so many martyrs, several bombing and explosions and political polarization, it draws attention as an interesting finding that clients do not talk about these issues. We can explain this issue by pathological grief. Horowitz suggests that pathological grief is a stress respond syndrome. Denial of pathological grief reveals itself as anger, shock, avoidance and unresponsiveness (as cited in Celik and Sayil, 2006). Instead of normal grief reactions, unexpected, exaggerated or extremely extended reactions or unresponsiveness might be developed; the reality of loss is not accepted (Bildik, 2013). People in pathological grief try to cover the facts making them uncomfortable and not to think about them. By this way, an incident is presumed as not existing and denied; in other words people write off the fact of terror, life-threatening situation, bombing and martyrs and ignore them as they create extreme sadness and stress. Stifling and erasing incidents from your memory is called pathological grief (as cited in Celik and Sayil, 2006). It is considered that these issues are not communicated due to pathological grief. In addition to this; if the Turkish culture is considered, while women go to a hairdresser to relax (Gokdag and Unugur), men go to a barber for a hair-cut on special days when they really need to go; in this sense, they do not feel it necessary to share their political views and opinions.

Other than these, while women prefer not to talk about sexual acts and etc. issues with hairdressers, men are more relax but they do not talk about their relatives, wives, sisters or mothers.

As a result of the study supporting the study of Gokdag and Unugur (2016); it is observed that hairdressers see their job "very exhausting" due to ergonomic conditions, long working hours and listening problems and complaints of their clients, they cannot be relieved by telling their problems with their clients. 
Briefly, according to the resources and studies in the literature, it can be indicated that different client-hairdresser relations can be developed in different cultures. It can be said that in Turkey, clients become loyal to the same hairdresser for a long time.

Even, in some resources, there are details that clients share their privacy in detail, according to the findings of this study, more than half hairdressers have mentioned that they have clients sharing superficially.

When the direction of communication (barber-customer and customer-customer) is examined, it is seen that there is an interesting difference. Male customers in barbers establish communication with their barbers rather than with other customers, while women in hairdressers communicate more with other women than with their hairdresser. One of the reasons for this could be the fact that women prefer to communicate with other women because their hairdressers are generally male. Another reason could be the fact that women are more curious than men and that women are thus ready to communicate with other customers.

This study is a pioneer for other researchers and studies in this field and within the context of wider cultural studies; it is recommended to expand the study for comparing male hairdresser with female hairdressers and the clients of male hairdressers with the clients of female hairdressers.

\section{References}

Baryaman, E. S., Aslan, M., Saltoglu, N., Yakar, H., Kocazeybek, B. \& Samasti, M. (2011). Esnaf ve Belediye Calışanlarında Hepatit B Seroepidemie yolojisinin Değerlendirilmesi ve Hepatit Sertifika Eğitimi Çalışması. Viral Hepatit Dergisi, 17 (1).

Batu, S., Kircaali Iftar, G., Uzuner, Y. (2004). Özel gereksinimli öğrencilerin kaynaştırıldığı bir kız meslek lisesindeki öğretmenlerin kaynaştırmaya ilişkin görüş ve önerileri. Ankara Üniversitesi Ĕ̆ $i$ tim Bilimleri Fakültesi Özel Eğitim Dergisi, 5 (2) 33-50.

Bildik, T. (2013). Ölüm, kayıp, yas ve patolojik yas. Ege Tip Dergisi, 52 (4).
Boztas, G., Cilingiroglu, N., Ozvaris, S. B., Karagoz, A., Karatas, F., Kara, G., Guzel, T. (2006). Ankara İlinin Bir Semtinde Bulunan Kuaför ve Güzellik Salonlarında Çalışan Kişilerin Kan Yoluyla Bulaş san Hastalıklar Konusunda Bazı Görüş ve Uygulał maları. Hacettepe Üniversitesi Hemşirelik Faküla tesi Dergisi, 13(1), 060-068.

Canyilmaz, D. (2009). Berber ve Kuafor Hizmetlerinde DAS Uygulamaları. 6. Ulusal Sterilizasyon Dezenfeksiyon Kongresi.

Caplan, M. (1998). Untouched: The Need for Genuine Affection in An Impersonal World. Hohm Press.

Celik, S., Sayil, I. (2006). Patolojik yas kavramına yeni bir yaklaşım: Travmatik yas. Kriz Dergisi, 11, 29-34.

Gokdag, R., Unugur, N. A. (May 2016). Female Hairdresser-Client Communication: What They Talk and What Secret They Share in Barber Armchairs! [Oral Presentation]. International Conference on Communication, Media, Technology and Design, Zagreb.

Guzel, D. (2013). Erzurum İlinde Faaliyet Gösteren Bayan ve Erkek Kuaförlerinin, Ergonomik Çalışma Koşulları, Mesleki Rahatsızlıklar ve İş Memnuniyeti Yönünden İncelenmesi. Atatürk Üniversitesi Sosyal Bilimler Enstitüsü Dergisi, 17(3), 345-358.

Mermer, G., Turk, M., Durusoy, R. (2015). Kadın Kue aförlerinin Çalışma Koşulları ve Mesleki Sağlık Soł runları. Mesleki Sağlık ve Güvenlik Dergisi, 14(5152).

Sahin, N. H., Bilgic, D., Esen, U., Cetinkaya, R., \& Tozoglu, Z. (2009). Bayan Kuaförü Çalışanlarının Hepatit B`ye İlişkin Bilgi ve Uygulamalarının Beł lirlenmesi. TAF Preven Med Bull, 8(2), 147-54.

Togan, T., Tosun, S., Turan, H., Arslan, H. (2014a). Aksaray İl Merkezinde Kuaför Çalışanlarının Her patit Konusundaki Bilgi Düzeyi ve Davranışlał r1. Ege Tip Dergisi, 53(4). 
Togan, T., Tosun, S., Turan, H., \& Arslan, H. (2014b). Manisa il merkezinde berber, kuaför ve güzellik salonu çalışanlarının Hepatit konusundaki bila gi düzeyi, tutum ve davranışları. Ankem Dergisi, 28(2), 50-57.

Yildirim, A.; Simsek, H. (2008). Nitel araştırma yöni temleri. Ankara: Seçkin Yayıncılık.

Yildirim, A.; Simsek, H. (2005). Sosyal bilimlerde nitel araştırma yöntemleri. Ankara: Seçkin Yayıncılık.

\section{Internet References}

"Adli Tip, Erdogan ve Davutoglu'nu yalanladi...Canli bomba Turkiye vatandasi, TAK'li cikti.... Cumhuriyet. Access date May 15 2016, http://www.cumhuriyet.com.tr/haber/turkiye/485563/Adli_Tip_ Erdogan_ve_Davutoglu_nu_yalanladi...Canli_ bomba_Turkiye_vatandasi_TAK_li_cikti....html

“Ankara Kizilay'da bombali saldiri: 37 olu”. NTV.com.tr. 14 Mart 2016. Access date May 152016, http://www. ntv.com.tr/turkiye/ankara-kizilayda-bombalisaldiri-37-olu,sxYYSU-FdUeqjI6Ok6GjdQ

“Ankara Tabip Odasi: Kayiplarimiz 106 kisi”. Dogan Haber Agency. October 14 2015. Access date May 15 2016, http://www.dha.com.tr/ankara-tabipodasi-kayiplarimiz-106-kisi_1048017.html

"Ankara saldirisini TAK ustlendi". BBC Turkish. March 17 2016. Access date May 15 2016, http:// www.bbc.com/turkce/haberler/2016/03/160317 tak_ankara_saldisi
"Ankara'da bombali saldiri: 28 kisi hayatini kaybetti". NTV.com.tr. February 22 2016. Access date May 15 2016, http://www.ntv.com.tr/turkiye/ankaradabombali-saldiri-28-kisi-hayatinikaybetti,zr83Fy9280ur1OzGAjqQwQ

"The Statement of the Prime Ministry Coordination Center". Prime Minister of the Republic of Turkey. October 11 2015. Access date May 15 2016, http://www.basbakanlik.gov.tr/Forms/_Article/ pg_Article.aspx?Id=4fb00379-6412-4b85-ba20$8 \mathrm{c} 8 \mathrm{c} 630 \mathrm{aec} 69$

"Guzellik salonlarina sosyal beklentiler icin de gidiliyor". Milliyet.com.tr. Access date May 15 2016, http://www.milliyet.com.tr/guzellik-salonlarina-sosyal-beklentiler--icin-de-gidiliyor-pembenardetay-ask-1656635/

"Hepimiz bu meslek sayesinde bir yerlere geldik." Hairist.com.tr. June 7 2013, access date May 15 2016, https://www.hairist.com.tr/mahmut_ebil_ hepimiz_bu_meslek_sayesinde_bir_yerlere_geldik.-278--.html

"Sacimi yapabilirsin, arkadasim olamazsin". Milliyet.com.tr. September 25 2011, Access date May 15 2016, http://www.milliyet.com.tr/sacimi-yapabilirsin-arkadasim-olamazsin/pazar/haberdetay/25.09.2011/1442733/default.htm

"Suruc'taki bombacinin kimligi kesinlesti”. Istanbul: Haberturk.com. July 21 2015. Access date May 15 2016, http://www.haberturk.com/gundem/ haber/1106032-suructaki-bombacinin-kimligikesinlesti 


\section{Interview Questions}

1a. What is your gender?
( ) a. Woman
( ) b. Man

1b. What is your level of education?
( ) a. Primary school/5 years
( ) b. Primary school/8 years
( ) c. High-school
( ) d. University or higher level

1c. How old are you?
( ) a. 25 and younger ( ) b. between 26-35
( ) c. between 36-45 ( ) d. 46 and over

2. How many years do you work as a hairdresser?
( ) a. 5-8 years
( ) d. 17-20 years
( ) b. 9-12 years
( ) e. 21-24 years
( ) c. 13-16 years
( ) e. 25 and more

3. How many years does your oldest client come to you?
( ) a. 5-8 years
( ) d. 17-20 years
( ) b. 9-12 years
( ) e. 21-24 years
( ) c. 13-16 years
( ) e. 25 and more

4. How many clients do you have who have been coming to you for five years and longer?
( ) a. 3 and less
( ) d. $10-12$
( ) b. 4-6
( ) e. $13-15$
( ) c. 7-9
( ) f. 16 and more

5. How many times do your old clients come to your shop in a month for a haircut, blow-dry, dyeing and etc.?
( ) a. 1 and less
( ) c. 3
( ) b. 2
( ) d. 4 and more 
6. How much time do these old clients spend in your shop?

The longest time The shortest time

( ) a. 10 minutes and less $\quad$ ( ) a. $1-1,5$ hours

$\begin{array}{ll}\text { ( ) b. 11-15 minutes } & \text { ( ) b. } 1,5-2 \text { hours }\end{array}$

$\begin{array}{ll}\text { ( ) c. } 16-20 \text { minutes } & \text { ( ) c. } 2-2,5 \text { hours }\end{array}$

( ) d. 21-25 minutes ( ) d. $2,5-3$ hours

( ) e. 26-30 minutes ( ) e. 3 hours and more

7. Do you have anyone among these old clients whom you are sincere and share secrets?

8. How many clients do you have sharing their secrets with you?

9. What is the estimated monthly income of secret sharing clients of you?

10. How old are the secret sharing clients of you?

11. Are the secret sharing clients of you mainly with profession?

12. What is the marital status of secret sharing clients of you? Married, single or divorced?

13. What are the subjects your clients share with you?

14. How much detail do they share with you?

15. What do you think the reason they share their secrets with you?

16. Do your secret sharing clients reopen the issue in their next visit?

17. Do you ask your clients about a previously shared secret by wondering any development?

18. Do your secret sharing clients caution you as "between you and me" or "do not ever tell anyone"?

19. Do you ever share any secret shared by a client to another one by mentioning or not mentioning any name?

20. Have you ever told any secret shared by any of your clients in conversations you held at different places with different people?

21. Do you ever share any secret shared by a client to another one on the phone?

22. Is there any situation where your clients ask for advice on any shared secret?

23. Do your clients confide in you and complaint about anything?

24. What are the issues they complain mostly?

25. What are your opinions and evaluations about your profession? 